\title{
The Assessment of Heavy Metals Concentration in Groundwater: A Case Study of the Wa Municipality
}

\author{
Hamidatu S. Darimani (Corresponding author) \\ Dept. of Agricultural Engineering, Wa Polytechnic \\ P.O Box 553, Wa, Upper West Region, Ghana
}

Tel: 233-020-788-0999Ｅ-mail: hamidnid2012@gmail.com

\author{
Jonathan Kwofie \\ Dept. of Agricultural Engineering, Wa Polytechnic \\ P.O Box 553, Wa, Upper West Region, Ghana
}

Tel: 233-0877-0302Ｅ-mail: jkreverends@yahoo.com

\begin{abstract}
Justine G. Tuolong
Department of Social, Political and Historical Studies

University for Development Studies, Wa - Campus, Ghana
\end{abstract}

Tel: 233-0934-7194Ｅ-mail: tuolong_justine@yahoo.com

Received: November 29, 2019 Accepted: December 22, 2019 Published: February 19, 2020

doi:10.5296/emsd.v9i1.15945 URL: https://doi.org/10.5296/emsd.v9i1.15945

\begin{abstract}
Water is a basic need for both domestic and industrial purposes. Regardless of the source of water it should not be contaminated. The purpose of this study is to establish the presence of heavy metals contaminants in groundwater in the Wa Municipality, Ghana. The study is an experiment of six (6) sample units which include: three (3) boreholes, two (2) wells and a sample from the Ghana Water Company Limited (GWCL) reservoir. The findings showed that Nitrite in JH1 $(3.65 \mathrm{mg} / \mathrm{l})$ and Iron in BM1 $(1.365 \mathrm{mg} / \mathrm{l})$ were beyond the benchmarks while other parameters in the rest of the sample units were within the World Health Organization (WHO) standards. Notwithstanding, the test was not significant $(p=0.359)$ at alpha 0.05 two tail test. The study concludes that the groundwater in the Wa Municipality is
\end{abstract}


not much contaminated and is safe for drinking with minimum treatment.

Keywords: Groundwater, Water quality, Contaminants, Heavy metals, Wa municipality

\section{Introduction}

In the management of water resources, the identification of heavy metals is primary important because of their influence on the quality of groundwater and consequently on the human beings. According to Vodela (1997) one of the most significant environmental issues today is groundwater contamination. It is underscored that heavy metals receive particular concern due to its wide diversity of contaminants affecting water resources considering their strong toxicity to organisms even at low concentrations. In Ghana, contaminations of surface and groundwater bodies have particularly been experienced in gold mining communities (Manu et al., 2004; Kuma and Younger, 2004; Obiri, 2007).

Pollution of groundwater is an impairment of water quality by chemicals, heat or bacteria to a degree that does not necessarily create public health hazards, but does adversely affect such water for domestic, farm, municipal or industrial use (Ogbonna et al., 2009; Oyatayo et al., 2015). Trace elements are generally present in small concentration in natural water system. Their occurrence in groundwater and surface water can be due to natural sources such as dissolution of naturally occurring minerals containing trace elements in the soil zone or the aquifer material or to human activities such as mining, fuels, smelting of ores and improper disposal of industrial wastes. According to Vodela (1997) and Cobbina et al. (2015) some common heavy metals that humans are exposed to include Mercury ( $\mathrm{Hg}$ ), Arsenic (As), Cadmium (Cd), Lead ( $\mathrm{Pb})$, Iron (Fe), Zinc ( $\mathrm{Zn})$, Copper (Cu) and Manganese (Mn). They further explained that high level of concentration of these metals in water may have various health effects on consumers.

The ever-increasing demand for water and non-existence of surface water to many people in the Wa Municipality, the people within these catchment areas resort to groundwater sources such as hand-dug wells and boreholes as their alternative water source. It is therefore important to assess the quality of groundwater (borehole water) to make sure it is safe for human consumption. It is empirically evidenced that, most diseases in groundwater can be associated with the presence of high concentration levels of heavy metals (Kortatsi, 2008; Cobbina et al. 2015). Therefore, water quality assessment is one of the most important aspects in groundwater quality control to safeguard human consumption. Consequently, ascertaining water quality for the purposes of domestic, commercial and industrial use can only be achieved by means of subjecting it to thorough chemical analysis since concentration levels of heavy metals cannot be detected by sight, smell or taste (MDH, EHD, WMS, 2014). The paper examines the extent of heavy metals elements concentration in groundwater in the Wa Municipality. The next sections discuss the research methodology which highlights the sampling site, codes and coordinates; data collection procedures and preparations; and analysis of results. Subsequently, the results of the data are discussed to inform the kind of conclusions finally arrived at in the study. 


\section{Methodology}

\subsection{Sampling Site}

In order to ascertain the contamination level of heavy metals in the study area, six (6) sites were selected for sample collection after investigating the activities in the study area. These include: Konta Mechanized Borehole (KM1), Jambori Open Well (JW1), Jahan Hand Pump (JH1), Ghana Water Company Limited (GWCL) reservoir (GW1), Dobile Mechanized Borehole (DM1), and Bamahu Mechanized Borehole (BM1). Below in Table 1 and Figure 3: indicates sample sites and designated code and coordinates using GPS, German 79 model.

Table 1. Sampling Sites and Coordinates

\begin{tabular}{|c|c|c|c|c|c|c|}
\hline \multirow[t]{2}{*}{$\mathbf{S} / \mathbf{N}$} & \multirow{2}{*}{$\begin{array}{c}\text { Sample } \\
\text { Location } \\
\text { Name }\end{array}$} & \multirow[t]{2}{*}{ Water Type } & \multirow{2}{*}{$\begin{array}{c}\text { Sample } \\
\text { Code }\end{array}$} & \multicolumn{3}{|c|}{ Coordinates } \\
\hline & & & & $\begin{array}{l}\text { Longitude } \\
\text { (Degrees) }\end{array}$ & $\begin{array}{l}\text { Latitude } \\
\text { (Degrees) }\end{array}$ & $\begin{array}{c}\text { Elevation } \\
\text { (M) }\end{array}$ \\
\hline 1.0 & Konta & Mechanized borehole & KM1 & 10.052 & 2.496 & 307 \\
\hline 2.0 & Jambori & Open Well & JW1 & 10.052 & 2.506 & 300 \\
\hline 3.0 & Jahan & Hand pump & JH1 & 10.059 & 2.486 & 330 \\
\hline 4.0 & GWCL-Reservoir & $\begin{array}{l}\text { Mechanized } \\
\text { boreholes }\end{array}$ & GW1 & 10.061 & 2.495 & 334 \\
\hline 5.0 & Dobile & Mechanized borehole & DM1 & 10.075 & 2.526 & 292 \\
\hline 6.0 & Bamahu & Mechanized borehole & BM1 & 10.012 & 2.481 & 292.5 \\
\hline
\end{tabular}

Source: Study Field Data (2016)

\subsection{Sample Collection}

Water samples were collected in two occasions (June - July, 2016) from three mechanized boreholes, two wells and one from GWCL reservoir within the study area using sterilized bottles. The sampling locations were established in the north-east, and south-west of the study area. A plastic bottle (1 litre) was used to collect the samples after been thoroughly sterilized and rinsed with de-ionized water to get rid of any probable contaminants. These plastic bottles were used to collect the water samples from each borehole and GWCL reservoir at each sample stage for analysis respectively.

\subsection{Preparations of Samples}

The sampling bottles (1 L capacity) were washed and rinsed in diluted nitric acid prior to use. Diluted nitric acid was poured into the sample bottles and the bottles were shaken properly so that the acid will react with the metals and some other particles. The bottles were left over night. They were then poured away the next day and rinsed with distilled water so as to get well purified or neutral sample bottles. The bottles were filled up to the brim during sampling. 


\subsection{Analysis Samples}

Water samples were kept in a refrigerator at $4^{\circ} \mathrm{C}$ after acidification with $1.5 \mathrm{ml}$ nitric acid. Thereafter, heavy metals in groundwater samples were analysed using Atomic Absorption Spectrophotometer for Arsenic (As), Iron (Fe), Manganese (Mn), Zinc ( $\mathrm{Zn})$, Copper (Cu) and Mercury $(\mathrm{Hg})$. These were done after the samples attained room temperature. Measurement with the Atomic Absorption Spectrophotometry method was recoded in milligram per litre $(\mathrm{mg} / \mathrm{l})$.

\subsection{Digestions of Water Samples}

Samples were preserved immediately after sampling by acidifying with concentrated nitric acid $\left(\mathrm{HNO}_{3}\right)$ to $\mathrm{pH}<2$ using a few drops of concentrated $\mathrm{HNO}_{3}$ per litre of sample. The acidified sample was stored in an iced packed container to maintain a temperature at approximately $4^{\circ} \mathrm{C}$ in order to prevent a change in volume due to evaporation, and to make sure that samples with metal concentration of several milligrams per litre are stable for up to 6 months. However, for microgram per litre metal levels, samples were analyzed as soon as possible after sample collection which was subjected to atomic absorption spectrophotometry (AAS) analysis. Concentration of manganese, iron, mercury, zinc, copper, nitrate and nitrite at the various locations were determined using the Atomic Absorption Spectrophotometer (Model No. HACH 2800). Also, Arsenic was analysed using HACH Arsenic Test Strips (Standard method).

\subsection{Procedure for Water Digestion}

To ensure the removal of organic impurities from the samples and prevent interference in analysis, the samples were digested with concentrated nitric acid $\left(\mathrm{NHO}_{3}\right) .10 \mathrm{ml}$ of nitric acid was added to $50 \mathrm{ml}$ of water in a $250 \mathrm{ml}$ conical flask. The mixture was evaporated to half its volume on a hot plate after which it was allowed to cool and then filtered as suggested by Matusiewicz (2005).

\subsection{Safety of Acid Digestions}

The reagents, instruments, and operations employed in the digestion of water are potentially hazardous, even when used as directed. Ensuring this, the operator was properly protected with a laboratory coat, gloves, and safety glasses and face protection. Some concentrated fuming acids $\left(\mathrm{HF}, \mathrm{HNO}_{3}, \mathrm{HCl}\right)$ were handled in a well-ventilated hood as suggested by Matusiewicz (2005).

\subsection{Statistical Analysis}

All statistical analyses in the study were performed using Microsoft Excel (2013 version). Mean values of the parameters were obtained from the field data and were juxtaposed with the WHO standard of water quality recommended for consumption. Afterwards, correlation and ANOVA: Two Factor without replication model was used to establish the relationship and the significance of the existence of heavy metal contaminants in groundwater. The test of significance was tested comparing the F-statistics and $p$-value $<0.05$ obtained from the ANOVA table. Data was presented using tables and charts. 


\section{Results and Discussions}

This section analyses and discusses the presence of heavy metals which includes: Arsenic (As), Zinc ( $\mathrm{Zn})$, Copper $(\mathrm{Cu})$, Iron $(\mathrm{Fe})$, Manganese $(\mathrm{Mn})$, Nitrate $\left(\mathrm{NO}_{3}\right)$, Nitrite $\left(\mathrm{NO}_{2}\right)$, and Mercury $(\mathrm{Hg})$ and its influences in groundwater. This was done to predict how groundwater in the Municipality is safe for consumption.

In Figure 1, the concentration levels of Arsenic in groundwater of samples varied from $0 \mathrm{mg} / \mathrm{l}$ to $0.0095 \mathrm{mg} / \mathrm{l}$. For example, the concentration of Arsenic in JW1 was $(0.0095 \mathrm{mg} / \mathrm{l})$, almost close to the WHO recommended benchmark $(0.01 \mathrm{mg} / \mathrm{l})$. This means the concentration level of Arsenic in JW1 despite still within the acceptable range, is close to being risky for consumption. This is not commendable and need to do better for safety consumption and use. Also, KM1 on the other hand was averagely $(0.004 \mathrm{mg} / \mathrm{l})$ within the WHO recommended benchmark. Aside the above, the other four (4) sample units (JH1, GW1, DM1, BM1) recorded $0 \mathrm{mg} / \mathrm{l}$. These mean those sample units, contained minimum Arsenic concentration.

According to Saracino and Phipps (2002), Arsenic is a natural occurring contaminant when percolated influences the accumulation of Arsenic concentrations high enough in groundwater makes it no longer safe for use without treatment. This confirms previous studies by WHO (2004) and Carr et al. (2012) who suggest that the intake or use of water having Arsenic above the drinking water standard may increase the risk of health problems of the skin, circulatory system, or the nervous system, including some cancers. Meaning the Arsenic level in JW1 has a long-term effect on users and should be avoided to assure users safety and quality of the water (MDH, EHD, WMS, 2014).

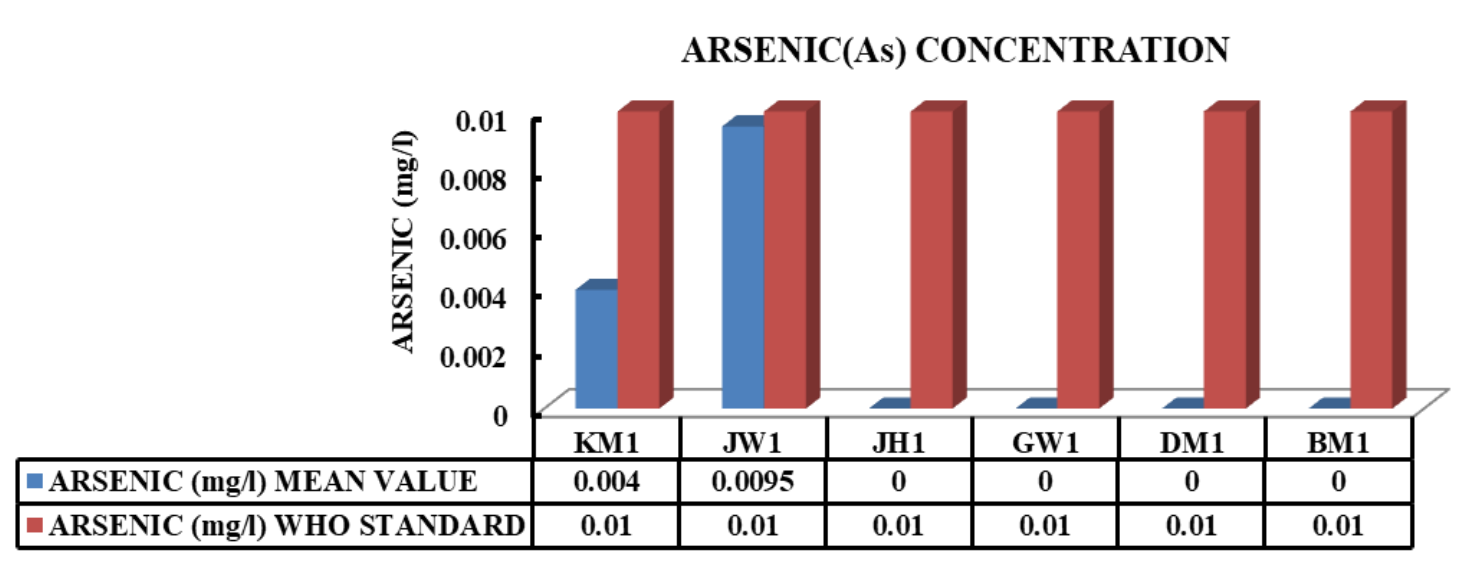

Figure 1. Mean Arsenic (mg/l) values of water from sampled boreholes and wells

Source: This Study Field Survey, June \& July Sample, 2016

Figure 2 showed that the concentration of Zinc did not vary significantly against the WHO permissible limits with a minimum mean value of $0 \mathrm{mg} / \mathrm{l}$ for $\mathrm{KM} 1$ and maximum of 0.065 $\mathrm{mg} / \mathrm{l}$ for GW1 which happened to be the sample from the Ghana Water Company reservoir. This means upon the treatment given by the GWCL their water recorded high presence of 


\section{Macrothink}

Zinc comparable to Boreholes and Wells. Similarly, JH1 had the second high record of Zinc $(0.035 \mathrm{mg} / \mathrm{l})$ followed by DM1 $(0.025 \mathrm{mg} / \mathrm{l})$ and BM1 $(0.01 \mathrm{mg} / \mathrm{l})$ even though they all fell within the WHO guideline limit of $5 \mathrm{mg} / \mathrm{l}$.

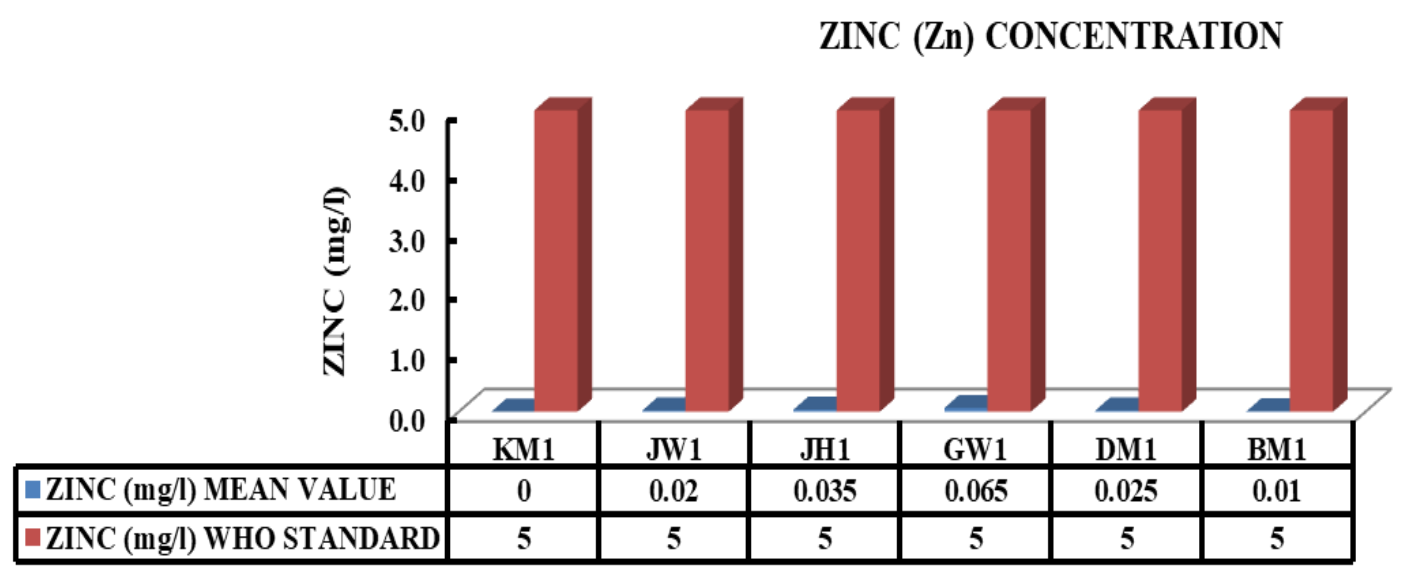

Figure 2. Mean Zinc (mg/l) concentrations of water from sampled boreholes and wells

Source: This Study Field Survey, June \& July Sample, 2016.

Therefore, this did not vary significantly from previous studies which in many studies found that, the presence of Zinc in groundwater despite falls within the WHO benchmark, it presence is always between $0.00-0.695 \mathrm{mg} / \mathrm{l}$ (Avdullahi et al., 2012; Hussain et al., 2012; Muiruri, 2013). According to Muiruri, (2013) the concentration level of Zinc close to 0.695 $\mathrm{mg} / \mathrm{l}$ is high and require treatment. Yet GW1 despite been treated often recorded the highest concentration $(0.065 \mathrm{mg} / \mathrm{l})$ level of Zinc in their supply to consumers.

Therefore, WHO (2003) suggest that, though levels of Zinc in groundwater and surface water normally should not exceed $0.01-0.05 \mathrm{mg} / \mathrm{l}$, but in the case of this study, GW1 had the maximum concentration level $(0.065 \mathrm{mg} / \mathrm{l})$ which exceeds the suggestion. Notwithstanding, the concentration of Zinc observed in this study all fell within the WHO permissible guideline value of $5 \mathrm{mg} / \mathrm{l}$. The mean concentrations of Zinc in this research were appreciably below the WHO guideline values and therefore pose no health threat to consumers. This is because Zinc is relatively non-toxic to humans but acutely and chronically toxic to aquatic organisms, particularly fish (WHO, 2003). Meaning GW1 may not be of a threat to human but to fish farming. 


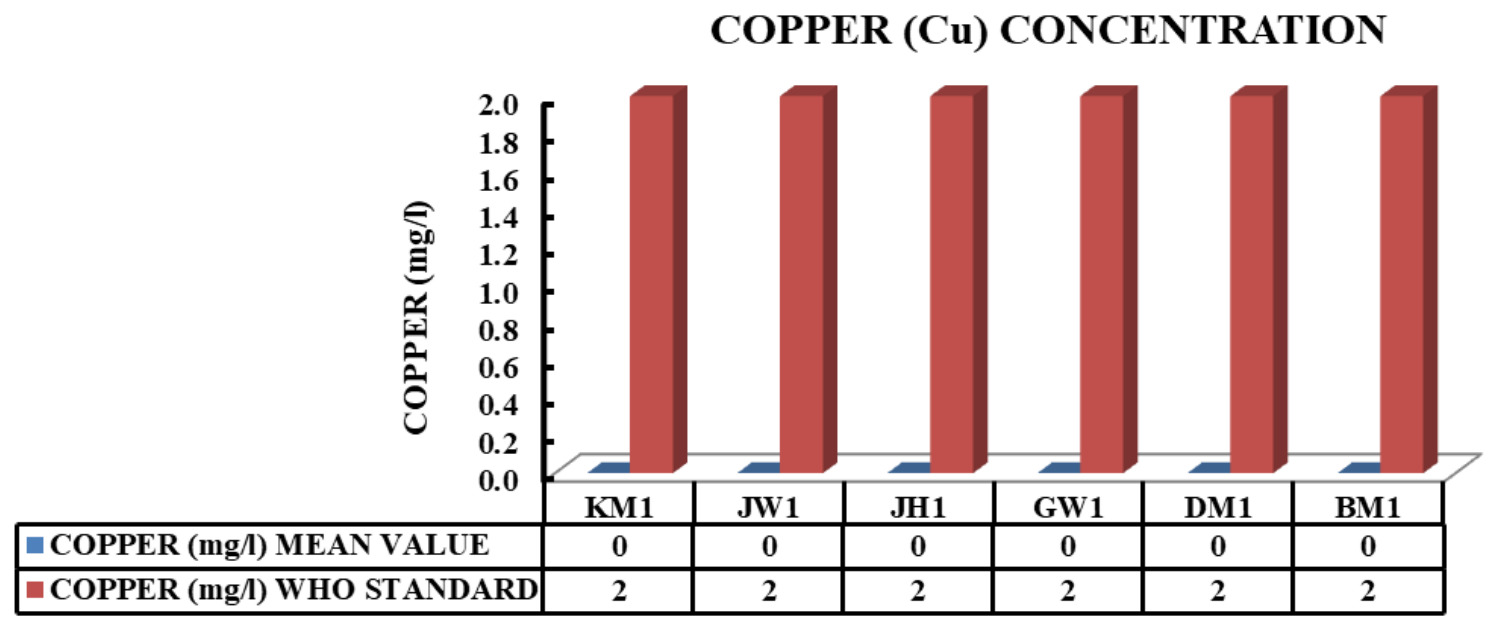

Figure 3. Mean Copper (mg/l) values of water from sampled boreholes and wells

Source: This Study Field Survey, June \& July Sample, 2016.

Copper is a metal that is naturally present in the environment, but it is suggested that the levels of contamination can be increased around agricultural land (manure spreading), near smelting facilities, and phosphate fertilizer plants (SDWF, 2007). In this study, the concentration of Copper $(\mathrm{Cu})$ was optimal $(0 \mathrm{mg} / \mathrm{l})$ across all the sample units against the WHO recommendation $(2 \mathrm{mg} / \mathrm{l})$. Thus, despite Copper is said to be a naturally present in the environment, in the study area its presence was at optimal $(0 \mathrm{mg} / \mathrm{l})$ and is commendable. This means that the activities around the study area do not pose major threat to discharge Copper constituents that could pose danger to the water bodies. This confirms Nolan (2003) assertion that the presence of Copper in water source is likely to be zero $(0 \mathrm{mg} / \mathrm{l})$ if the study area is not under activities that influences its existence which the Wa Municipality is no exception.

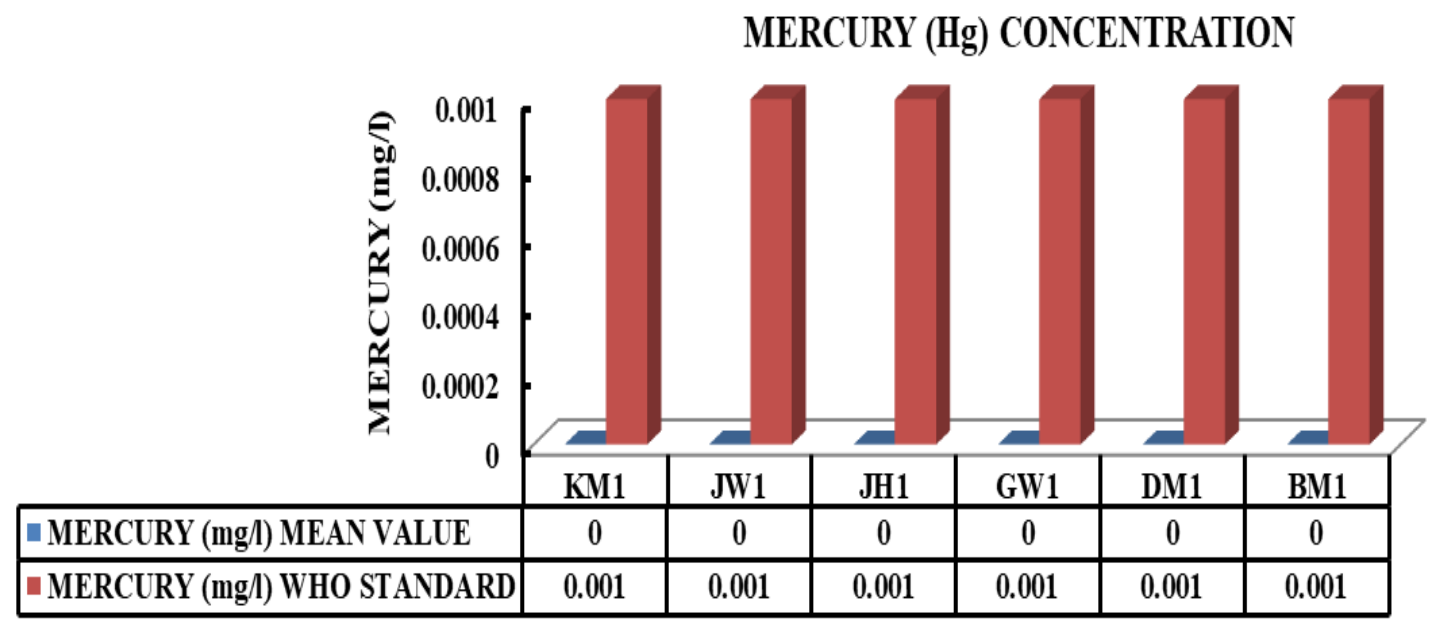

Figure 4. Mean Mercury (mg/l) values of water from sampled boreholes and wells Source: This Study Field Survey, June \& July Sample, 2016. 


\section{Macrothink}

Environmental Management and Sustainable Development

ISSN 2164-7682

2020, Vol. 9, No. 1

In Figure 4, Mercury was also found to be optimal $(0 \mathrm{mg} / \mathrm{l})$ among all the sample units in both June and July samples. These all were optimally below to the WHO recommended benchmark $(0.001 \mathrm{mg} / \mathrm{l})$. Meaning the concentration levels of Mercury in the study area are commendable because samples fell within the permissible limits specified in the WHO guidelines.

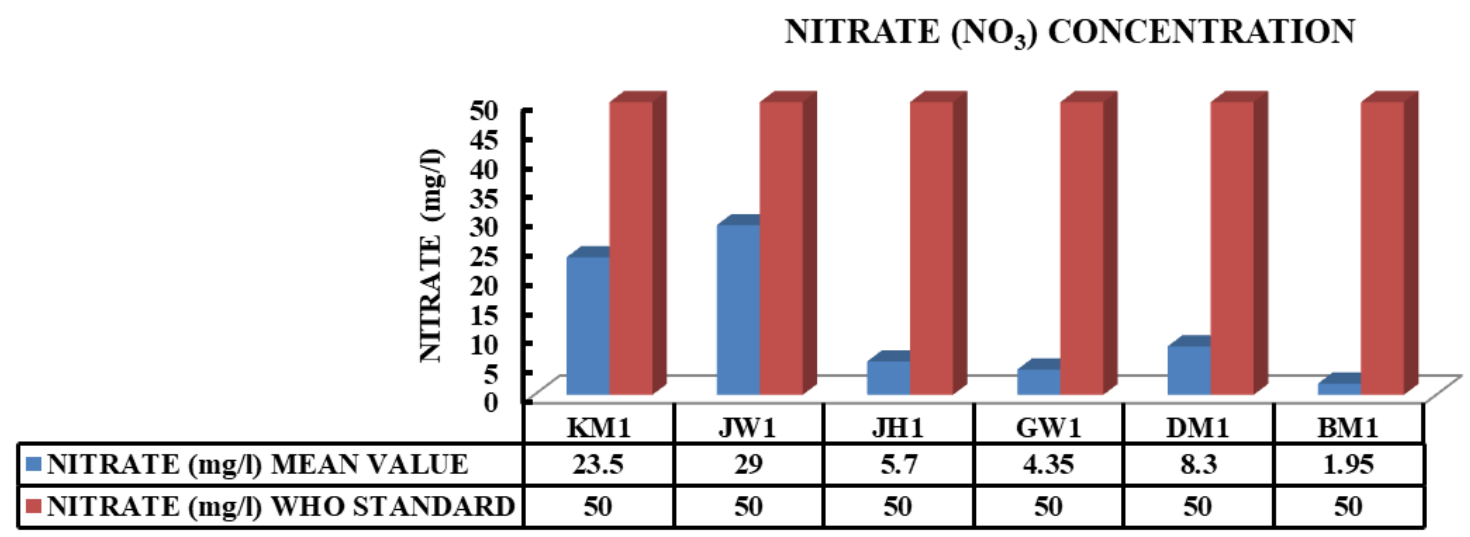

Figure 5. Mean Nitrate (mg/l) concentrations of water from sampled boreholes and wells Source: This Study Field Survey, June \& July Sample, 2016.

In Figure 5, Nitrate all across the sample units was within the recommended range $(50 \mathrm{mg} / \mathrm{l})$. Among the samples, JW1 and KM1 had average $(29.0 \mathrm{mg} / \mathrm{l}$ and $23.5 \mathrm{mg} / \mathrm{l})$ concentration level of Nitrate below the WHO standards respectively. Notwithstanding, BM1 recorded the lowest concentration of Nitrate $(1.95 \mathrm{mg} / \mathrm{l})$. From the survey, it was observed that JW1 was an open-well situated approximately $25 \mathrm{~m}$ away from a refuse dump-site which have influenced the high level of Nitrate found. Again, the research observed that the Nitrate concentration recorded among hand dug-wells were much higher than those of the boreholes. This did not vary largely from previous studies by Karikari (2013) and Nyamekye (2013).

NITRITE $\left(\mathrm{NO}_{2}\right)$ CONCENTRATION

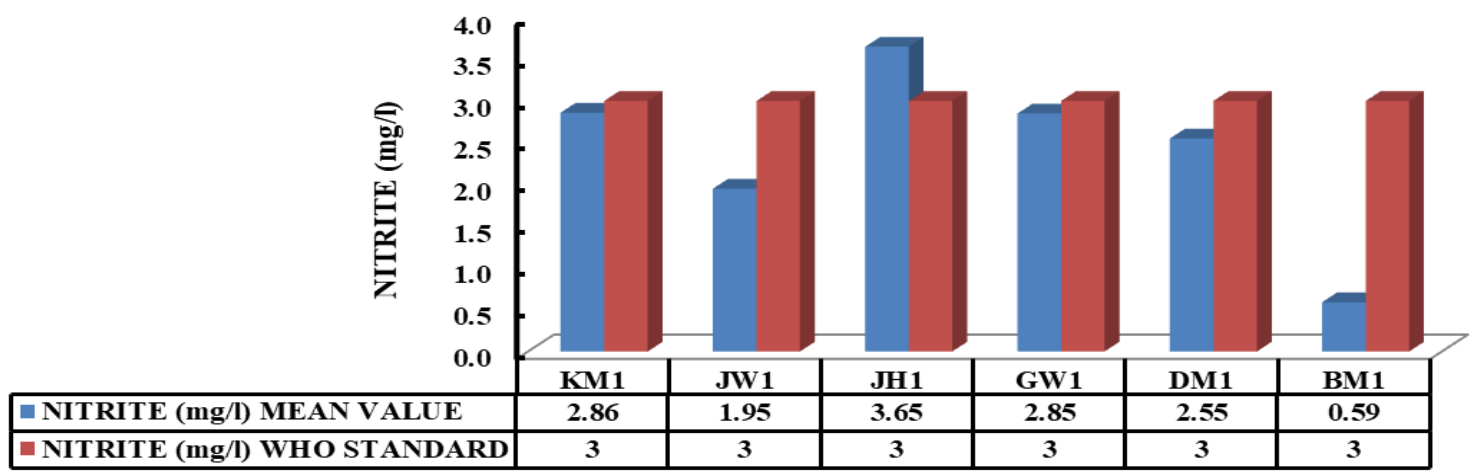

Figure 6. Mean Nitrite (mg/l) concentrations of water from sampled boreholes and wells Source: This Study Field Survey, June \& July Sample, 2016. 


\section{Macrothink}

On the concentration of Nitrites in the sampled units, JH1 recorded the highest value $(3.65$ $\mathrm{mg} / \mathrm{l})$ averagely above the WHO benchmark (3 mg/l). Also, KM1, GW1 and DM1 despite within benchmark (i.e. $2.86 \mathrm{mg} / \mathrm{l}, 2.85 \mathrm{mg} / \mathrm{l}$ and $2.55 \mathrm{mg} / \mathrm{l}$ ) respectively but were close to recommendation $(3 \mathrm{mg} / \mathrm{l})$ with the exception of BM1 which was far below $(0.59 \mathrm{mg} / \mathrm{l})$ the WHO maximum recommended standard of $3 \mathrm{mg} / \mathrm{l}$. The high concentration of Nitrite in $\mathrm{JH} 1$ is because there is an increase use of compound fertilizer and grazing of livestock at the site location therefore influenced the results. This, previous studies have subjected the high concentration of Nitrite in groundwater to be the cause of seepage (Fewtrell, 2004; McCasland et al., 2012). Addo et al., (2011) suggested that high Nitrites concentration in groundwater is an indication of pollution due to biological pollutants in natural waters. Also, WHO (2011) adds and said the presence of Nitrites in elevated concentrations is an indication of organic pollution in the water body (WHO, 2011).

In Figure 7, sample units; BM1 (1.365 mg/l) and JW1 $(0.42 \mathrm{mg} / \mathrm{l})$ again had the presence of Iron exceeding the WHO recommended benchmark of $0.3 \mathrm{mg} / \mathrm{l}$. Notwithstanding, KM1 $(0.215 \mathrm{mg} / \mathrm{l}), \mathrm{JH} 1(0.215 \mathrm{mg} / \mathrm{l}), \mathrm{DM} 1(0.245 \mathrm{mg} / \mathrm{l})$ and GW1 $(0.13 \mathrm{mg} / \mathrm{l})$ had their iron fallen within the WHO recommendation but were close to the $0.3 \mathrm{mg} / \mathrm{l}$ benchmark. Among all, the Ghana Water Company sample (GW1) had the lowest presence of iron in groundwater and this commendable for their effort despite the fact that it is their core mandate to ensure consumers or users water safety. From observation at site, the researchers found that the water from BM1 had an offensive odour and taste. The JW1 site was is located close to a refuse dump-site approximately $25 \mathrm{~m}$ from the well. It is therefore argued that, these factors could have influenced the high concentration of Iron present in those sample units as the experiment predicted. The results in this studies contradict Likambo (2014) who found that in urban areas, the presence of Iron on groundwater is often minimal $(0.017 \mathrm{mg} / \mathrm{l})$ as most sample units varied (e.g. $0.215 \mathrm{mg} / \mathrm{l})$ with the exception of GW1 $(0.13 \mathrm{mg} / \mathrm{l})$ despite Wa Municipality is also classified as urban community.

\section{IRON (Fe) CONCENTRATION}

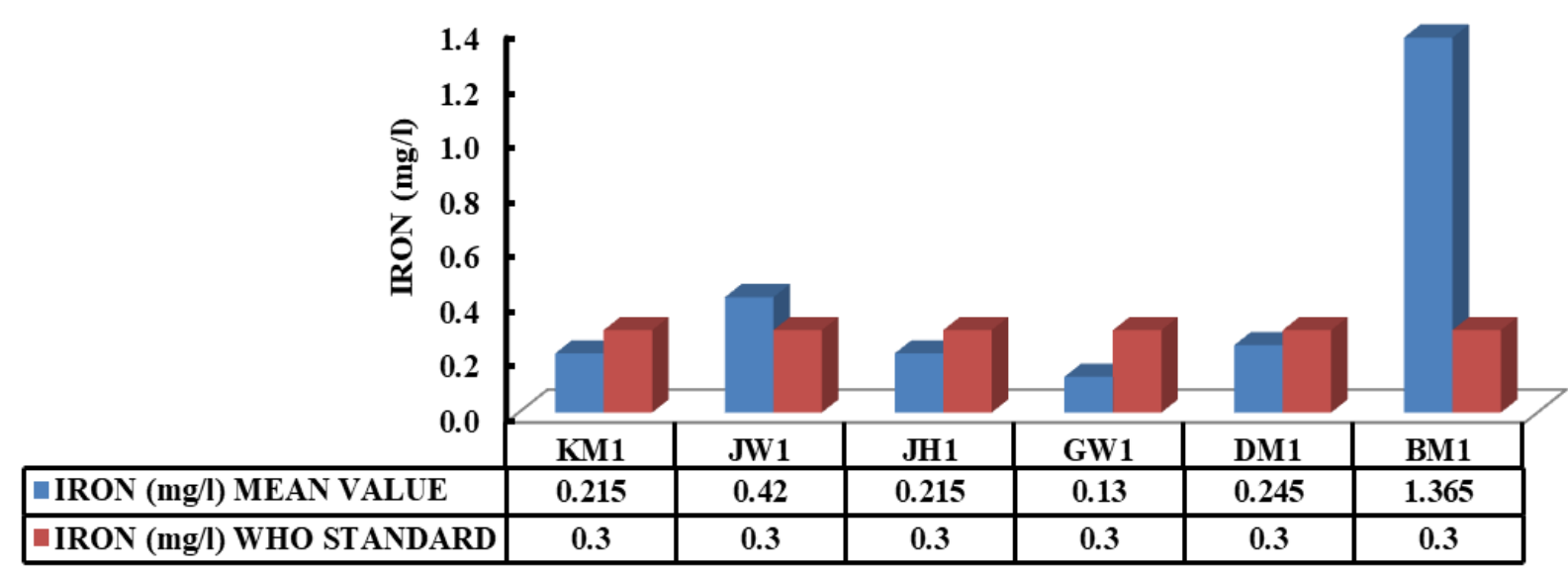

Figure 7. Mean Iron (mg/l) concentrations of water from sampled boreholes and wells

Source: This Study Field Survey, June \& July Sample, 2016. 


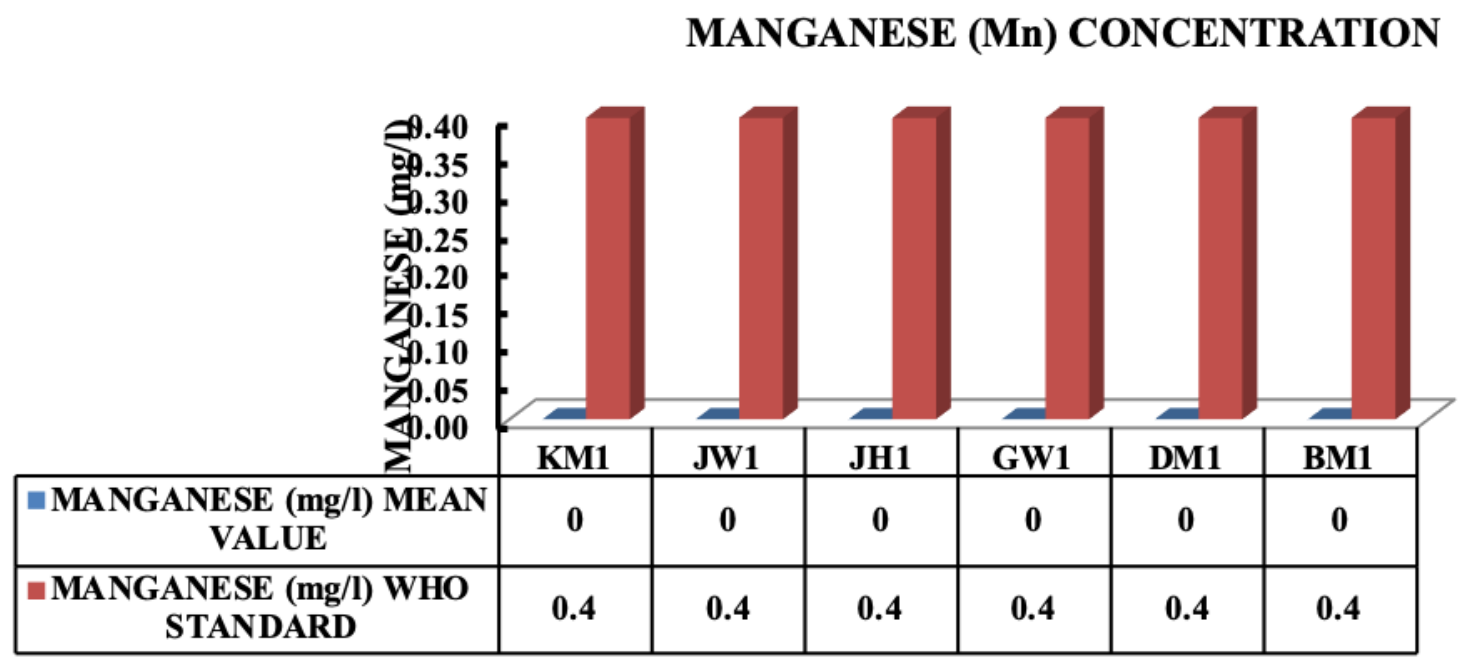

Figure 8. Mean Manganese (mg/l) concentrations of water from sampled boreholes and wells Source: This Study Field Survey, June \& July Sample, 2016.

Figure 8 measures the presence of Manganese in sampled units. Results obtained shows that all the sample units have optimal $(0 \mathrm{mg} / \mathrm{l})$ existence of Manganese in boreholes and wells. Meaning there was no Manganese in the boreholes and wells surveyed in the Wa Municipality and this commendable to have met the WHO limit of $0.4 \mathrm{mg} / \mathrm{l}$. Therefore, despite Manganese occurs naturally in groundwater human activities and others (Olumuyiwa et al., 2012); these pose no effect in terms of Manganese contaminants in the water samples. Therefore, do not pose health threat to consumers.

\subsection{Statistical Analysis Using Correlation and ANOVA Two-Factor without Replication}

This section analyses the correlation between heavy metals tested as well as their statistical significance. Table 2 and 3 below presents on the correlation and Anova: Two Factor without replication of parameters and their effect.

Table 2. The Correlation between Heavy Metal Parameters in Groundwater

\begin{tabular}{|l|l|l|l|l|l|l|l|l|}
\hline PARAMETERS & ARSENIC & ZINC & COPPER & MERCURY & NITRATE & NITRITE & IRON & MANGANES \\
\hline ARSENIC & 1 & & & & & & & \\
\hline ZINC & -0.35944 & 1 & & & & & & \\
\hline COPPER & $* *$ & $* *$ & 1 & & & & & \\
\hline MERCURY & $* *$ & $* *$ & $* *$ & 1 & & & & \\
\hline NITRATE & 0.937829 & -0.46323 & $* *$ & $* *$ & 1 & & & \\
\hline NITRITE & -0.12496 & 0.407523 & $* *$ & $* *$ & 0.06705 & 1 & & \\
\hline IRON & 0.150576 & -0.78124 & $* *$ & $* *$ & 0.308973 & -0.31278 & 1 & \\
\hline MANGANES & $* *$ & $* *$ & $* *$ & $* *$ & $* *$ & $* *$ & $* *$ & 1 \\
\hline
\end{tabular}

Source: This Study Field Survey, June \& July Samples, 2016.

Two-tail test at alpha: 0.05 NB: Sample Units $=6$ : **Denotes constant values depicting no significance effect 
In Table 2, the results showed that there was weak negative relationship between Arsenic and Zinc (-0.359) and Nitrite (-0.125) but had a strong positive correlation with Nitrate (0.938) and weak on Iron (0.151). This means when Arsenic is high or low in a sample, there was an inverse reduction or increase of Zinc, and Nitrite but increase or reduce consistently with nitrate and iron. However, the presence of arsenic in a sample had no effect on Copper, Mercury, and Manganese.

Also, Zinc had fair negative relationship with Nitrate (-0.463), positive with Nitrite $(0.408)$ but was strong and negatively correlated with Iron (-0.781). Again, there was weak positive effect between Nitrate and Nitrite (0.067) and iron (0.309) while Nitrite also had weak inverse effect on Iron (-0.313). This mean the presence of Nitrate in water had little influence on Nitrite and Iron but Nitrite has reverse effect on Iron. Notwithstanding, the presence of Copper, Mercury and Manganese has no effect on the other parameters (Arsenic, Zinc, Nitrate, Nitrite, and Iron).

Table 3. ANOVA: Two-Factor without Replication on Heavy Metals in Groundwater

\begin{tabular}{|l|l|l|l|l|l|l|}
\hline Source of Variation & $S S$ & $D f$ & $M S$ & $F$ & $P$-value & Fcrit \\
\hline Samples & 84.48374 & 5 & 16.89675 & 1.05904 & 0.39946 & 2.485143 \\
\hline Parameters & 745.4069 & 7 & 106.4867 & 6.674283 & $4.8 \mathrm{E}-05$ & 2.285235 \\
\hline Error & 558.4172 & 35 & 15.95478 & & & \\
\hline Total & 1388.308 & 47 & & & & \\
\hline
\end{tabular}

Source: This Study Field Survey, June \& July Sample, 2016.

Two-tail test at alpha: 0.05

Table 3 established the significance of the presence of heavy metals per the parameters measured in groundwater (sample units) in the Wa Municipality. Out of the test, the results proofed not to be significant ( $p$-values $=0.399$ and 4.805 ) at the chosen alpha 0.05 level. This means there was little presence of heavy metals per those parameters measured in those sampled units indicating that, groundwater is safe from contaminants of heavy metals for domestic consumption and use. The result is possible because the study area had few activities such as mining, high use of compound fertilizers and others that could influence the presence of heavy metals in groundwater.

\section{Conclusion}

Upon successful investigations, the findings from the experiment discovered that Nitrite $\left(\mathrm{NO}_{2}\right)$ and Iron (Fe) exceeded the WHO recommended benchmark. In samples (JH1 \& BM1), the concentration of Nitrite and Iron threatened consumer's health. Aside, parameters such as Arsenic (As), Zinc ( $\mathrm{Zn})$, Copper $(\mathrm{Cu})$, Mercury $(\mathrm{Hg})$, Manganese $(\mathrm{Mn})$ and Nitrate $\left(\mathrm{NO}_{3}\right)$ possessed optimal health risk on consumers and could be risky if there should be any further influences. However, Manganese $(\mathrm{Mn})$, Copper $(\mathrm{Cu})$ and Mercury $(\mathrm{Hg})$ in the six samples posed utmost 'no' health risk on consumers and very recommendable. Therefore, the statistical test showed there was no significant effect $(p$-value $=0.399)$ of the presence of 
heavy metals as measured in this study in groundwater. Thus, the study found groundwater in the Wa Municipality possess minimum health threats to consumers.

\section{References}

Addo, M. A., Darko, E. O., Gordon, C., \& Nyarko, B. J. B. (2011). Water quality analysis and human health risk assessment of groundwater from open-wells in the vicinity of a cement factory at Akporkloe, Southeastern Ghana. http://197.255.68.203/handle/123456789/6268

Avdullahi, S., Islam F., Ahmet, T., Mursel, R., \& Muhamedin, H., (2012). Assessment of Heavy Metals in the Water Springs, Stan Terg, Kosovo. International Journal in Engineering and Applied Science, 2(4), 12-17.

http://eaas-journal.org/survey/userfiles/files/2\%20geo\%20science\%20_heavy\%20Metals.pdf

Carr, G. M., \& Neary, J. P. (2012). Water Quality for Ecosystem and Human Health, $2^{\text {nd }}$ Edition. [Online] Available: http://wedocs.unep.org/handle/20.500.11822/12217

Cobbina, S. J., Abudu B. D., Reginald Q., Samuel O., \& Noel B., (2015). Comparative Assessment of Heavy Metals in Drinking Water Sources in Two Small-Scale Mining Communities in Northern Ghana (Online). https://dx.doi.org/10.3390\%2Fijerph120910620

Fewtrell, L., \& Colford, J. (2004). Water, Sanitation and Hygiene: Interventions and Diarrhoea: A Systemic Review and Meta-analysis. Washington: World Bank. [Online] Available: http://siteresources.worldbank.org/HEALTHNUTRITIONANDPOPULATION/ Resources/281627-1095698140167/Fewtrell\&ColfordJuly2004.pdf

Hussain, J., Jehangir, S., Iktiar, K., Wilson, A. L., Rosemario, C. S., ... Iracema, A. N. (2012). American-Eurasian Journal of Agriculture \& Environmental Science, 12(8), 1091-1094.

Karikari, B. N. (2013). Physico-chemical and Bacteriological Assessment of Selected Boreholes and Hand-dug Wells in New Edubiase, Ashanti Region. [Online] Available: http://ir.knust.edu.gh/xmlui/handle/123456789/5323

Kortatsi, B. K., Anku, Y. A., \& Anornu, G. K. (2008). Characterization and appraisal of facets influencing geochemistry of groundwater in the Kulpawn sub-basin of the White Volta Basin, Ghana. Environmental Geology Journal, 16(3), 8-9.

http://dx.doi.org/10.1007/s00254-008-1638-9

Kuma, J. S., \& Younger, P. L. (2004). Water quality trends in the Tarkwa Gold-mining district, Ghana. Bulleting in Engineering, Geology Environment, 63(1), 119-132. https://doi.org/10.1007/s10064-004-0227-8

Likambo, W. (2014). Assessment of Borehole Water Quality and Consumption in Yei County, South Sudan. [Online] Available: http://makir.mak.ac.ug/handle/10570/3377

Manu, A., Twumasi, Y. A., \& Coleman, T. L. (2004). Application of remote sensing and GIS technologies to assess the impact of surface mining at Tarkwa, Ghana (Volume 1, 572-574). In Proceedings of the IEEE Geoscience and Remote Sensing Symposium, Anchorage, AK, USA. 


\section{Macrothink}

Environmental Management and Sustainable Development

ISSN 2164-7682

2020, Vol. 9, No. 1

Matusiewicz, H. (2005). Wet Digestion Methods. Politechnika Poznanska, Department of Analytical Chemistry. pp. 60-965.

McCasland, M., Trautman, N. M., \& Porter, K. S. (2012). Natural Resources Cornell Cooperative Extension. Nitrate: Health Effects in Drinking Water.

MDH, EHD, WMS (2014). Well owners handbook. A consumer's guide to water wells in Minnosota.

Muiruri, M.J. (2013). Determination of Concentrations of Selected Heavy Metals in Tilapia Fish, Sediments and Water from Bagathi and Ruiru Athi River Tributaries. Kenya. [Online] Available: https://ir-library.ku.ac.ke/bitstream/handle/123456789/9067/Mwangi\%2c\%20JohN $\%$ 20Muiruri.pdf?sequence $=1 \&$ isAllowed $=\mathrm{y}$

Nolan, K. (2003). Copper toxicity syndrome. Journal of Orthomolecular Psychiatry, 12(1), 270-282.

Nyamekye, E. (2013). An Investigation Into Quality Of Water From Private Hand-Dug Wells Sited In Close Proximity To On-Site Sanitation Systems In Households Of Small Towns: A Case Study Of Kintampo Municipality In Brong-Ahafo Region, Ghana. [Online] Available: http://dspace.knust.edu.gh/handle/123456789/6312?mode=full

Obiri, S. (2007). Determination of heavy metals in boreholes in Dumasi in the Wassa west district of western region of the Republic of Ghana. Environment and Monitoring Assessment, 127(1), 455-463. https://doi.org/10.1007/s10661-006-9435-y

Ogbonna, D. N., Kii, B. L., \& Youdeowel, P. O. (2009). Some Physico-chemical and Heavy Metal levels in Soil of waste dump-site in Port Harcourt Municipality and Environmental. Journal in Applied Science, Environment and Management, 13(4) 65-70.

https://doi.org/10.4314/jasem.v13i4.55414

Olumuyiwa, I. O., Otieno, F. A., \& Ochieng, G. M. (2012). Groundwater: Characteristics, qualities, pollutions and treatments. International Journal of Water Resources and Environmental Engineering, 4(6), 162-170. https://doi.org/10.5897/IJWREE12.038

Oyatayo, K. T., Songu, G. A., \& Amos, G. A. (2015). Assessment of Heavy Metal Concentration in Hand Dug Well Water from Selected Land Uses in Wukari Town. Wukari, Taraba State Nigeria. Journal of Geoscience and Environment Protection, 3(1), 1-10. https://doi.org/10.4236/gep.2015.39001

Safe Drinking Water Foundation-SDWF (2007). Water Quality Test. [Online] Available: https://www.safewater.org/mission

Saracino, A., \& Phipps, H. (2002). Groundwater contaminants and contaminants sources. [Online] Available: http://groundwater.ucdavis.edu/files/136257.pdf

Vodela, J. K., Renden, J. A., Lenz, S. D., McElhenney, W. H., \& Kemppainen, B. W. (1997). Drinking water contaminants (arsenic, cadmium, lead, benzene, and trichloroethylene). 1. Interaction of contaminants with nutritional status on general performance and immune 


\section{Macrothink \\ Environmental Management and Sustainable Development \\ ISSN 2164-7682 \\ 2020, Vol. 9, No. 1}

function in broiler chickens. Poultry Science, 76(11), 1474-1492.

https://doi.org/10.1093/ps/76.11.1474

WHO (2004). Guidelines for Drinking Water Quality, (Third Edition). Volume 1: Recommendations. World Health Organization, Geneva. [Online] Available:

https://www.who.int/water_sanitation_health/dwq/GDWQ2004web.pdf

World Health Organization (2011). Guidelines for Drinking-Water Quality, WHO Press, Geneva, Switzerland, 4th edition. [Online] Available:

https://www.who.int/water_sanitation_health/publications/2011/dwq_guidelines/en/

World Health Organization WHO (2003). Chromium, zinc, lead, in drinking-water. Background document for preparation of WHO Guidelines for drinking-water quality, Geneva, (WHO/SDE/WSH/03.04/4).

\section{Copyright Disclaimer}

Copyright for this article is retained by the author(s), with first publication rights granted to the journal.

This is an open-access article distributed under the terms and conditions of the Creative Commons Attribution license (http://creativecommons.org/licenses/by/3.0/). 